\title{
INITIAL EPIDEMIOLOGICAL FINDINGS IN THE EUROPEAN UNION FOLLOWING THE DECLARATION OF PANDEMIC ALERT LEVEL 5 DUE TO INFLUENZA A (H1N1)
}

\author{
ECDC Technical Emergency Team (annick.lenglet@ecdc.europa.eu)1,2 \\ 1. European Centre for Disease Prevention and Control, Stockholm, Sweden \\ 2. The members of the team are listed at the end of the article
}

\begin{abstract}
The recent detection of a novel influenza $A(H 1 N 1)$ virus has led to the first WHO declaration of a Public Health Event of International Concern under the International Health Regulations (IHR 2005). Here we review the early epidemiological findings of confirmed cases in Mexico, the United States, Canada and EU/EFTA countries. Strengthened surveillance and continued, transparent communication across public health agencies globally will be necessary in coming months.
\end{abstract}

\section{Background}

Infections with swine influenza virus have been detected occasionally in humans since the 1950s and the resulting human disease is usually similar to human influenza viral infections [1-6]. Complications, including pneumonia and death, have been reported in the literature in adults without underlying disease [7]. Chains of human-to-human transmission had not previously been observed apart from an outbreak among young adult military recruits in New Jersey in 1976, causing 230 infections, 13 of whom were severe with one death [8].

On 21 April, the European Centre for Disease Prevention and Control (ECDC) was alerted of the existence of cases of respiratory illness in the United States (US) caused by a novel influenza virus [9]. On 23 April 2009, cases from Mexico were confirmed to be caused by influenza $\mathrm{A}(\mathrm{H} 1 \mathrm{~N} 1)$ virus. Initial cases in the US demonstrated no exposure to pigs, and some were clustered. In Mexico, the outbreak caused cases of severe respiratory illness and suspected deaths $[9,10]$.

Preliminary investigations showed that six genomic segments of the virus were related to swine viruses from North America and the remaining two were from swine viruses isolated in Europe and Asia [11]. The virus was resistant to adamantanes, but susceptible to neuraminidase inhibitors $[9,12]$.

On 25 April, the World Health Organization (WHO) declared this event a 'Public Health Event of International Concern' under the framework of the International Health Regulations (IHR 2005). On 26 April, New Zealand, Spain and the United Kingdom (UK) started investigating persons returning from Mexico with influenzalike symptoms. On 27 April, the first confirmed cases of the new influenza $A(H 1 N 1)$ were reported from Spain $(n=1)$ and the UK $(n=3)$ in travellers returning from Mexico, and 10 additional European Union (EU) countries reported investigating cases.

On 27 and 29 April, WHO raised the pandemic alert phases to 4 and 5 , respectively. Governments were requested to strengthen surveillance, to detect and treat cases early and implement infection control in all health facilities.

In the EU, the European Commission recommended that countries extend their routine seasonal influenza surveillance beyond week 20. Additionally, on 30 April 2009, an EU case definition for the novel influenza $A(H 1 N 1)$ virus was agreed upon by EU Member States [13].

A timeline of the events is shown in the Figure.

This article aims to review the preliminary epidemiological findings in the EU following the identification of influenza A (H1N1) in Mexico and the US.

\section{Current global epidemiological situation}

As of 7 May, 2,217 confirmed cases of influenza A(H1N1) have been confirmed worldwide, from 24 countries located in three WHO regions [14].

\section{Countries not in the EU and European Free Trade Association (EFTA) (Non-EU/EFTA countries)}

In Mexico, the epidemiological profile of 866 out of a total of 1,112 confirmed cases shows that the majority of cases occurred in the area around Mexico City ( $n=496,53.8 \%)$ [15]. Forty-two deaths have been confirmed [14]. Fifty percent of cases are female and $49 \%$ of confirmed cases are under the age of 19 years [15].

In the US, 41 out of 50 states have reported 745 confirmed cases of the new influenza $\mathrm{A}(\mathrm{H} 1 \mathrm{~N} 1)$ [14]. Two deaths and 35 hospitalisations were reported. The median age of confirmed cases is 16 years, and $62 \%$ are under the age of 18 years [16].

Canada reported 201 confirmed cases of the new influenza $\mathrm{A}(\mathrm{H} 1 \mathrm{~N} 1)$ with one hospitalisation of a young girl [17]. Eight of 10 provinces and none of the territories have reported confirmed cases, with the majority reported from British Colombia $(n=54)$, Nova Scotia $(n=53)$ and Ontario $(n=49)$ [18]. 
Sporadic cases have been reported from New Zealand, the Republic of Korea, Hong Kong, Israel, Costa Rica, Guatemala, Colombia and El Salvador.

\section{EU and EFTA countries}

Thirteen EU/EFTA countries have confirmed 142 cases since 27 April (Table 1). The majority of confirmed cases are from Spain

F I G U R E

Timeline of major events: new influenza A(H1N1) outbreak, April 2009

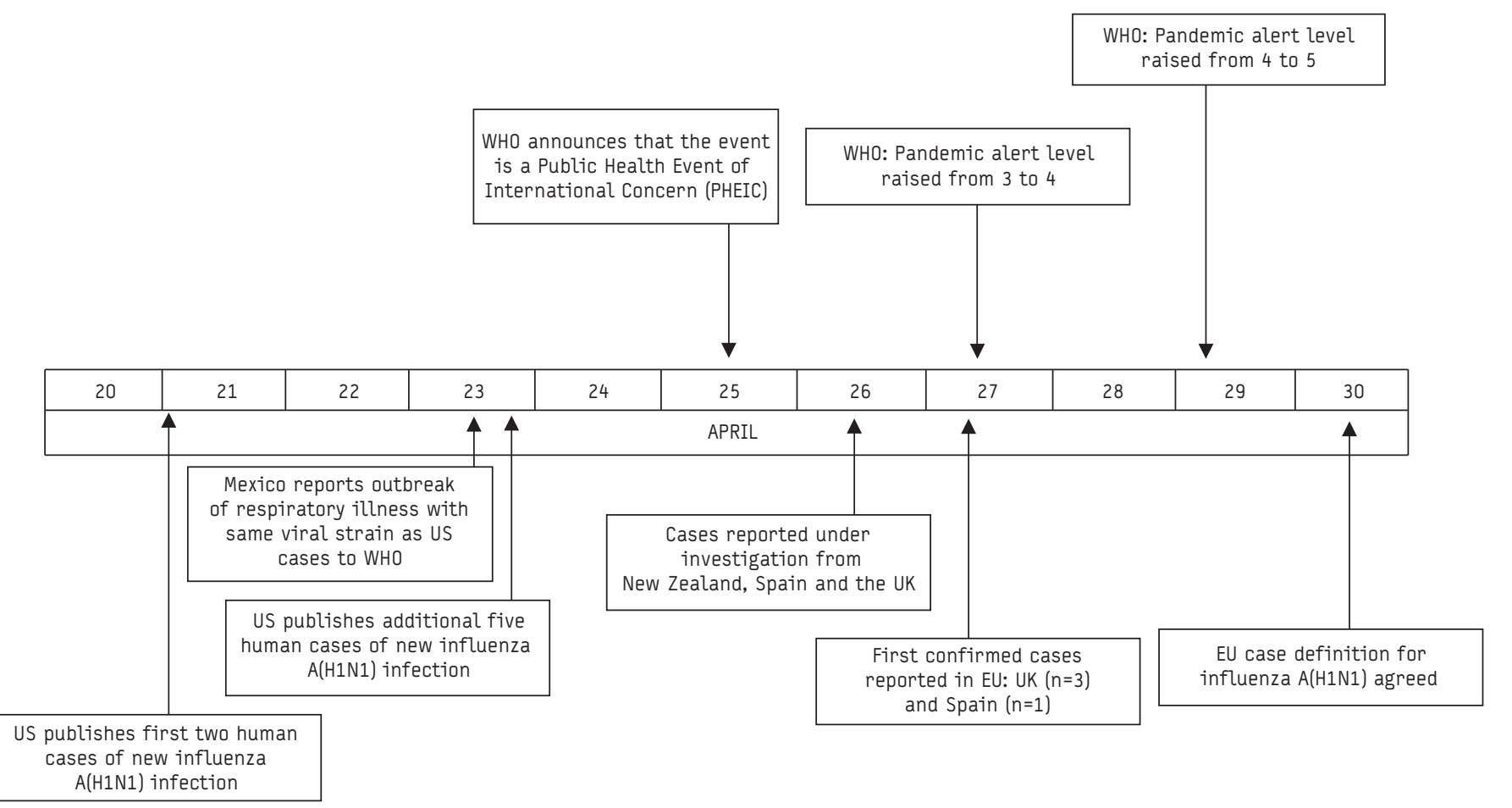

EU: European Union; UK: United Kingdom; US: United States; WHO: World Health Organization.

T A B L E 1

Reported current number of probable cases, cumulative number of confirmed cases and cumulative number of in-country transmission, influenza $\mathrm{A}(\mathrm{H} 1 \mathrm{~N} 1)$ outbreak 2009*

\begin{tabular}{|c|c|c|c|}
\hline Country & Current number of probable cases & Cumulative number of confirmed cases & Cumulative number of in-country transmission \\
\hline Austria & - & 1 & - \\
\hline Denmark & 0 & 1 & - \\
\hline France & 3 & 7 & - \\
\hline Germany & 0 & 9 & 2 \\
\hline Ireland & 0 & 1 & - \\
\hline Italy & - & 5 & - \\
\hline Netherlands & - & 1 & - \\
\hline Poland & - & 1 & - \\
\hline Portugal & 0 & 1 & - \\
\hline Spain & - & 81 & 5 \\
\hline Sweden & 0 & 1 & - \\
\hline Switzerland & - & 1 & - \\
\hline United Kingdom & 1 & 32 & 10 \\
\hline Total & 4 & 142 & 17 \\
\hline
\end{tabular}

Data as of 7 May 2009, 8:00 hours (CEST) in European Union (EU) and European Free Trade Association (EFTA) countries [14].

Note: cases reported in the EU and EFTA countries correspond to the EWRS notifications by Member States or Ministry of Health websites. 
$(n=81)$ and the UK $(n=32)$. Age and gender data are available for 35 confirmed cases (Table 2). The male-female sex ratio is 1.5 , the median age is 23 years (range $3-50$ years), and $49 \%$ of cases are between 20 and 29 years of age.

Seventeen confirmed cases (16\%) acquired the infection through transmission within the EU. In Germany, a nosocomial cluster occurred in a nurse and patient who were exposed to a hospitalised confirmed case. Spain reported five autochthonous transmissions and the UK reported 10, including a cluster of five school children exposed to a confirmed schoolmate with travel history to the US. There is no indication of transmission occurring in the EU outside of close contacts of known cases.

Countries within the European Union have coordinated their public health measures on the basis of EU communicable disease legislation. The measures taken include: information to the public and travellers, raising awareness amongst healthcare workers and enhancing surveillance for influenza-like illness. On the basis of a risk assessment provided by the European Centre for Disease Prevention and Control (ECDC), the European Commission collaborates closely with the Member States, international organisations and third countries to ensure a coordinated response to this event on the EU level.

\section{Discussion}

Three out of six WHO regions have confirmed cases. However, community transmission, defined as transmission chains spreading beyond close contacts into the community, has to date only occurred in Mexico and in the US. EU/EFTA countries are still experiencing limited chains of transmission to close contacts of returning travellers from Mexico and the US.

Based on the experience from Mexico and the US, it appears that seeding events established by travellers from affected areas are occurring in closed community settings such as schools. The spread of the virus within these settings causes an amplification of the viral reservoir in the communities ultimately leading to community spread. In the EU, some confirmed cases have already been reported in children of school age and in close school contacts and monitoring of these events should continue to be done carefully.

\section{T A B L E 2}

Gender and age distribution of confirmed cases in EU and EFTA countries, influenza A(H1N1) outbreak $2009(n=35)$

\begin{tabular}{|l|c|c|c|}
\hline Age group (years) & Female & Male & Total \\
\hline $0-9$ & 1 & 0 & 1 \\
\hline $10-19$ & 2 & 1 & 3 \\
\hline $20-29$ & 7 & 10 & 17 \\
\hline $30-39$ & 1 & 3 & 4 \\
\hline $40-49$ & 1 & 2 & 3 \\
\hline $50-59$ & 0 & 1 & 1 \\
\hline$>59$ & 0 & 0 & 0 \\
\hline Unknown & 2 & 4 & 6 \\
\hline Total & $14(40 \%)$ & $21(60 \%)$ & 35 \\
\hline
\end{tabular}

EFTA: European Free Trade Association (EFTA); EU: European Union.
Half of the confirmed cases observed in the EU are between 20 and 29 years of age. This finding is influenced by the age structure of returning travellers among which most of the testing is carried out in EU/EFTA countries. It therefore does not indicate that this age group is at higher risk of disease. Most cases in the EU/EFTA countries are mild. However, more severe clinical presentation may be expected when the infection will spread in the general population.

Most of the efforts in the EU/EFTA countries are currently directed at detecting returning travellers from areas with community outbreaks, namely Mexico and the US. However, considering how the outbreak is progressing, the focus of surveillance is now shifting to the timely detection of community transmission. EU Member States are currently continuing their surveillance of seasonal influenza. As the national influenza centres are now all equipped with reagents to identify the novel influenza $A(H 1 N 1)$ strain, it is likely that cases that may occur in the community in the EU will be detected by virological surveillance.

\section{Conclusion}

It is still too early to predict how the outbreaks of influenza A (H1N1) will evolve in the EU/EFTA countries. Data from Mexico and the US suggest that this novel virus spreads rapidly in the communities once introduced from an affected area.

Continued strengthened surveillance efforts, coordination and information sharing amongst countries on a global level will support the EU and other affected countries in their preparedness and response for the potential spread of this novel influenza virus in the weeks and months to come.

\section{Members of the ECDC Technical Emergency Team:}

A Navarro Torne, A Cassini, A Ammon, A Amato-Gauci, A Nicoll, A Jansson, A Magiorakos, A Lenglet, B Ciancio, C Varela Santos, C Gossner, C Ködmön, D Coulombier, E Depoortere, F Plata, F Santos O'Connor, G Likatavicius, H Gomes, H Zeller, J Mantero, J Giesecke, J Suk, K Leitmeyer, K Johansen, L Payne, L Pastore Celentano, M Salminen, N Ciampa, 0 Heuer, P Vasconcelos, P Arias Bohigas, P Kreidl, P Zucs, P Kramarz, R Snacken, R Filipe, S Lyson, S Tsolova, S Rehmet, T Mollet, V Lopez, V Bremer, V Prikazsky.

\section{References}

1. Kluska V, Macku M, Mensik J. [Demonstration of antibodies against swine influenza viruses in man]. [In Czech]. Ceskoslovenska pediatrie. 1961;16:40814.

2. Dowdle WR, Hattwick MA. Swine influenza virus infections in humans. The Journal of infectious diseases. 1977;136 Suppl:S386-9.

3. Myers KP, Olsen CW, Gray GC. Cases of swine influenza in humans: a review of the literature. Clin Infect Dis. 2007;44(8):1084-8.

4. Olsen CW, Karasin AI, Carman S, Li Y, Bastien N, Ojkic D, et al. Triple reassortant H3N2 influenza A viruses, Canada, 2005. Emerg Infect Dis. 2006;12(7):1132-5.

5. Gray GC, MCCarthy T, Capuano AW, Setterquist SF, Olsen CW, Alavanja MC. Swine workers and swine influenza virus infections. Emerg Infect Dis..2007;13(12):1871-8.

6. Newman AP, Reisdorf E, Beinemann J, Uyeki TM, Balish A, Shu B, et al. Human case of swine influenza A (H1N1) triple reassortant virus infection, Wisconsin. Emerg Infect Dis. 2008;14(9):1470-2.

7. Van Reeth K. Avian and swine influenza viruses: our current understanding of the zoonotic risk. Veterinary research. 2007;38(2):243-60.

8. Gaydos JC, Top FH, Jr., Hodder RA, Russell PK. Swine influenza a outbreak, Fort Dix, New Jersey, 1976. Emerg Infect Dis. 2006;12(1):23-8.

9. Swine Influenza A (H1N1) infection in two children--Southern California, March-April 2009. MMWR Morb Mortal Wkly Rep. 2009;58(15):400-2. 
10. Outbeak of swine-origin influenza $A(H 1 N 1)$ virus infection - Mexico, MarchApril 2009. MMWR Morb Mortal Wkly Rep. 2009;58(Dispatch):1-3.

11. Trifonov V, Khiabanian H, Greenbaum B, Rabadan R. The origin of the recent swine influenza $A(H 1 N 1)$ virus infecting humans. Euro Surveill. 2009;14(17):pii=19193. Available online: http://www.eurosurveillance.org/ ViewArticle.aspx?ArticleId $=19193$

12. Update: drug susceptibility of swine-origin influenza A (H1N1) viruses, April 2009. MMWR Morb Mortal Wkly Rep. 2009;58(16):433-5.

13. European Commission. Commission Decision of 30 April 2009, 2009/363/EC. 2009. Available from: http://eur-lex.europa.eu/LexUriServ/LexUriServ.do?uri =0J:L:2009:110:0058:0059:EN:PDF

14. European Centre for Disease Prevention and Control. ECDC Situation Report, Influenza A (H1N1) infection, Update May 7, 2009, 8:00 hours CEST; 2009. Available from: http://www.ecdc.europa.eu/en/files/pdf/Health_topics/ Situation_Report_090507.pdf

15. Ministry of Health Mexico. Situacion actual de la epidemia. [Current epidemic situation]. [In Spanish]. 2009. Available from: http://portal.salud.gob.mx/ descargas/pdf/influenza/presentacion20090505.pdf

16. US Centers for Disease Control and Prevention (CDC). CDC Briefing on Investigation of Human Cases of H1N1 Flu, May 5, 2009. 2009. Available from: http://www.cdc.gov/media/transcripts/2009/t090505.htm

17. Public Health Agency of Canada (PHAC). Cases of H1N1 Flu Virus (Human Swine Flu) in Canada. 2009. [Accessed 6 May, 2009]. Available from: http://www. phac-aspc.gc.ca/alert-alerte/swine-porcine/surveillance-eng.php

This article was published on 7 May 2009.

Citation style for this article: ECDC Technical Emergency Team. Initial epidemiological findings in the European Union following the declaration of pandemic alert level 5 due to influenza A (H1N1). Euro Surveill. 2009;14(18):pij=19204. Available online: http://www.eurosurveillance.org/ViewArticle.aspx?ArticleId=19204 